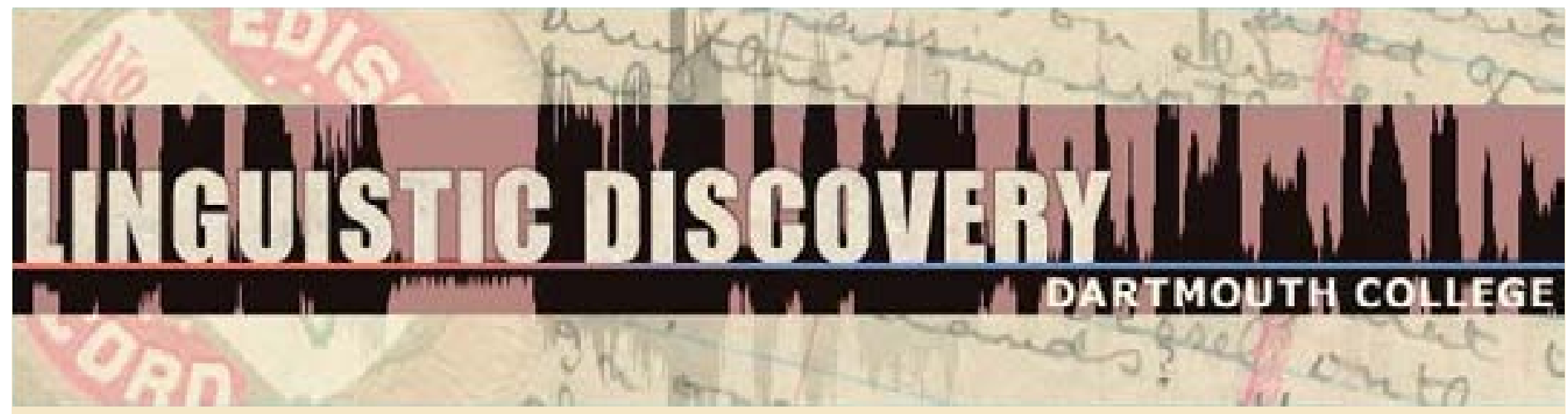

\begin{tabular}{|l|}
\hline Volume 10 \\
Issue 3 \\
2012 \\
\hline
\end{tabular}

\title{
Ditransitive Alignment in Yakima Sahaptin
}

Joana Jansen

University of Oregon

doi: 10.1349/PS1.1537-0852.A.415

url: http://journals.dartmouth.edu/cgi-bin/WebObjects/ Journals.woa/1/xmlpage/1/article/415

\section{Linguistic Discovery}

Published by the Dartmouth College Library Copyright to this article is held by the authors. ISSN 1537-0852 linguistic-discovery.dartmouth.edu 


\section{Ditransitive Alignment in Yakima Sahaptin ${ }^{1}$ \\ Joana Jansen \\ University of Oregon}

The grammatical coding of monotransitive and ditransitive clauses in Sahaptin (Plateau Penutian) demonstrates sensitivity to a range of factors, including animacy, person, topicality and number. The language over-codes participants throughout transitive paradigms, violating principles of economy in both flagging and indexing patterns. For example, a third person agent argument of any monotransitive or ditransitive verb may be case marked in one of three ways, depending on the properties of other participants. In this paper I discuss the categories of ditransitive clauses and describe the multiple ditransitive alignment patterns in the Yakima dialect of Sahaptin.

\section{Introduction}

This paper examines ditransitive clauses in the Yakima dialect of Sahaptin, describing three classes of underived ditransitives and two classes of derived ditransitives. Hierarchies of animacy, topicality and person affect the formal coding of monotransitive and ditransitive clauses. The language exhibits monotransitive as well as ditransitive alignment splits, reflected in the case marking of monotransitive subjects (A) and objects $(\mathrm{O})$, and ditransitive themes $(\mathrm{T})$ and recipients/goals $(\mathrm{R})$. In some monotransitive and ditransitive constructions, morphological coding is invariant, while in others speakers can choose how to code arguments. Both monotransitives and ditransitives exhibit a high degree of redundancy in participant coding, resulting in systems that are less than economical.

The Sahaptin and Nez Perce languages comprise the Sahaptian Family, classified as a member of the Plateau branch of Penutian (DeLancey and Golla 1997). Sahaptin speakers of a number of related dialects live in the southern plateau region of the Pacific Northwest of the United States, along Nch 'iwána 'Columbia River' and its tributaries. The dialects are mutually intelligible. Rigsby (1965) describes three groups of Sahaptin dialects: Northeast (NE) dialects, spoken along the Columbia River from Priest Rapids to the lower Yakima and Snake Rivers; Northwest (NW), spoken mainly in the Yakima River drainage; and Columbia River (CR), spoken along the Columbia east of what is now The Dalles, Oregon, and along the Deschutes, John Day, and Umatilla Rivers.

Sahaptin is a synthetic to polysynthetic language with rich verbal morphology. The phonemic inventory is similar to other Pacific Northwest languages and consists of a large set of consonants and small set of vowels. Stops and affricates are voiceless with a plain and glottalized series. Grammatical relations are indicated with case-marking, verb agreement and pronominal enclitics; the language is both head and dependent-marking. Sahaptin shows hierarchical alignment, hierarchically motivated inverse marking and split ergativity. Syntactic alignment is primarily accusative. Arguments are often covert; many clauses consist of the verb only. Word order is flexible, serving discourse/pragmatic functions.

${ }^{1}$ I thank the European Science Foundation, the Jacobs Fund and the Endangered Languages Documentation Programme for their support of this research and fieldwork contributing to this research. The feedback of Eva van Lier has significantly improved this paper, as have the comments of two anonymous reviewers. Scott DeLancey, Spike Gildea, and Noel Rude's input is gratefully acknowledged. I also thank and acknowledge my Yakima Sahaptin consultants. All errors and omissions are my own. 
This paper makes use of data from the Yakima dialect (NW). ${ }^{2}$ The data are from recorded and analyzed texts collected by the author and from consultation with two elders. The language is severely endangered; there are only a handful of fluent Yakama elders who speak Sahaptin as their first language, all of whom also speak English. Estimates of number of speakers range from 5 to 25 . There are determined revitalization efforts to return the language to daily use within the Sahaptin communities. All language data are presented using the Yakima practical alphabet. ${ }^{3}$

\section{Monotransitive Constructions}

There are four subclasses of verbs: intransitive, optionally transitive, transitive, and ditransitive. A small set of verbs can take both transitive and intransitive morphology and so fall into the 'optionally transitive' category. Transitivity is morphologically indicated and thus the transitivity of a verb can be determined by morphological tests.

Grammatical relations in Sahaptin are well-defined, and are morphologically indicated. The discussion below describes the grammatical relations of transitive subject and transitive object, here labeled $\mathrm{A}$ and $\mathrm{O}$ following Dixon (1994). Transitive combinations are coded morphologically by verb prefixes, second position enclitics, and, in the case of overt noun phrases (NP), case markers. Independent pronouns are used for emphasis and disambiguation only. Of particular interest here, Sahaptin has grammatical systems that are sensitive to referential hierarchies. In most ways, these mirror prototypical systems that show sensitivity to an indexability hierarchy (as discussed by, for example, Nichols 1992, Siewierska 2004, Zúnĩga 2006) in which $1^{\text {st }}$ and $2^{\text {nd }}$ persons, i.e., speech act participants (SAP) outrank third persons, animate entities outrank inanimates, and topical participants outrank less-topical participants. However, the Sahaptin system exhibits breaks from the more usual patterns. Like typical inverse direction systems, Sahaptin uses a verbal inverse marker when second person acts on first and when an obviative third person (3OBV) acts on a proximate third person (3PRX). This marker does not, however, occur when third person acts on an SAP. Like typical hierarchical alignment, Sahaptin has a set of person markers that specify SAP in opposition to third and second person in opposition to first. However, there is not an unambiguous ranking of first and second. Casemarking is also hierarchy-sensitive, with third person subjects potentially bearing one of two obviative/ergative markers, depending on the person of the object, and differential object marking based on animacy and topicality.

The following sections discuss the properties of monotransitive clauses. The sections are organized by participant combinations, moving from mixed (SAP/3) to local (SAP/SAP) to nonlocal (3/3) scenarios. For the purposes of this paper, only examples with a singular subject are discussed; plurality in some scenarios overrides person and topicality hierarchies. For example,

\footnotetext{
${ }^{2}$ Speech community members refer to the dialects by their individual names, or by the collective terms Ichishkíin or Sahaptin. The Yakama Nation began to use the spelling Yakama in 1994. I use the spelling Yakima to refer to the dialect described here, and Yakama when referring to the Yakama Nation and members of the Yakama Nation. My primary collaborator, Virginia Beavert, uses the spelling Yakima because previous elders chose iiyaakii'ma as the best representation of the name of the language and tribe (Beavert-Martin 1999). Here, I follow her guidance and preference.

${ }^{3}$ The differences between the Yakima practical alphabet and the Americanist alphabet are: (1) The Yakima practical alphabet uses an underscored $(\mathrm{k})(\mathrm{k})$ for uvular stop q, and an underscored $\mathrm{x}(\mathrm{x})$ for uvular fricative $\chi$; (2) digraphs used in the Yakima alphabet are: $\mathrm{sh}-\breve{\mathrm{s}}, \mathrm{ch}-\check{\mathrm{c}}, \mathrm{t}-\chi, \mathrm{xw}-\mathrm{k}^{\mathrm{w}}, \underline{\mathrm{x}}-\chi^{\mathrm{w}}$.
} 
unlike singular third person A, plural third person A is not case marked nor does it co-occur with inverse marking on the verb.

Of importance throughout the paper is the grammatical coding of SAP arguments, which are indicated by second position pronominal enclitics that follow the first word of the clause. Case marking of these enclitics displays neutral alignment, with the same form used for subjects and objects. The examples below show first person singular enclitic =nash, as intransitive subject in example (1), transitive subject in example (2), and object in example (3).

$$
\begin{aligned}
& \text { aw nash wyátamayksha } \\
& \text { aw =nash wyá-łamayk-sha } \\
& \text { now =1SG while.going-lose-IMPV }{ }^{4} \\
& \text { 'Now I am getting lost' }
\end{aligned}
$$

$$
\begin{array}{ll}
k u \text { nash ák'inuta } & \\
k u \quad=n a s h & a-k \text { 'inu-ta } \\
\text { and }=1 \mathrm{sG} & 30-\mathrm{oee}-\mathrm{FUT}
\end{array}
$$

'and I will see him/her/them'

$$
\begin{aligned}
& \text { ku nash ik'ínuta } \\
& k u \quad=\text { nash } \quad i-k \text { 'ínu-ta } \\
& \text { and =1sG } \quad 3 \text { SG.S/A-see-FuT } \\
& \text { 'and s/he will see me' }
\end{aligned}
$$

\subsection{Mixed}

In clauses with a first or second person subject and a third person object, the second position pronominal enclitic references the SAP A. The verb has the prefix á- (allomorph áw-is seen below) indicating a third person object. If the object is overt it may be (but is not obligatorily) case marked with the object suffix -nan (SG), -inan (DL) or -maman (PL).

$$
\begin{aligned}
& \text { Cháw nash ánach'axi áwitł'yawita k áxnumaman. } \\
& \begin{array}{lllll}
\text { chaw } & =\text { nash } & \text { ánach'axi } & \text { áw-ítt'yawi-ta } & \underline{k} \text { káxnu-maman } \\
\text { NEG }=\mathbf{1 S G} & \text { again } & \text { 3o-kill-FUT } & \text { prairie.chicken-OBJ.PL }
\end{array}
\end{aligned}
$$

'I'll never again kill prairie chickens'

Differential object marking in Sahaptin is sensitive to animacy and topicality. Third person human objects are consistently case marked. Animate (non-human) and inanimate objects are optionally marked.

\footnotetext{
${ }^{4}$ Abbreviations are as follows: 1 first person, 2 second person, 3 third person, A agent, ABS absolutive, APPL applicative, CAUS causative, CSL cislocative, DAT dative, DIR direct, DL dual, ERG ergative, FUT future, GEN genitive, HAB habitual, HUM human, IMPV imperfective, INV inverse, NEG negative, O object, OBJ object, OBV obviative, PL plural, PN pronoun, PPF present perfect, PRX proximate, PST past, R recipient, S/A subject of intransitive/agent of transitive, SAP speech act participant, SG singular, T theme.
} 
When a third person acts on an SAP, the pronominal enclitics indicate the SAP. The verb prefix is the third person singular marker $i$-. The third person NP, if present, takes the ergative case marker -nim.

$$
\begin{aligned}
& \text { Íkush nash ishapáttawaxiñxana Xaxáishnim } \\
& \text { íkush =nash i-shapá-ttáwax-inxa-na Xaxíish-nim } \\
& \text { thus } \quad=1 \mathbf{S G} \quad 35 \mathrm{SG} . \mathrm{S} / \mathrm{A} \text {-CAUS-grow-HAB-PST } \underline{X} \text { axísh-3>SAP.ERG } \\
& \text { 'In that way, } \underline{X} \text { axísh raised me' }
\end{aligned}
$$

\subsection{Local}

When first person acts on second, a complex pronominal enclitic is used. In configurations with first person singular acting on second person singular, this complex form is =mash, seen in (6).

$$
\begin{aligned}
& \text { shápnisha mash } \\
& \text { shápni-sha = mash } \\
& \text { ask-IMPV =1SG>2SG } \\
& \text { 'I'm asking you' }
\end{aligned}
$$

In the reverse scenario, when second person singular acts on first person singular, the second person enclitic $=$ nam (here shortened form $=a m$ ) is used, along with the prefix pá-, here called an inverse prefix. As will be seen below, the prefix pá-is also used when 3OBV acts on 3PRX.

$$
\begin{aligned}
& \text { páshapnishaam } \\
& \text { pá-shápni-sha }=\mathbf{a m}^{5} \\
& \text { INV-ask-IMPV=2SG } \\
& \text { 'You're asking me' }
\end{aligned}
$$

Note that in example (7), there is no overt indication of the first person argument. The combination of prefix and enclitic is what specifies that the object is first person. If an independent first person pronoun is used, that pronoun will be in the object case, as in (8).

$$
\begin{aligned}
& \text { inák nam páshapnisha } \\
& \text { inák =nam pá-Shápni-sha } \\
& \text { 1SG.PN.OBJ =2SG INV-ask-IMPV } \\
& \text { 'You're asking me' }
\end{aligned}
$$

There is not an unambiguous ranking of first and second persons, as coding systems compete. The inverse verb prefix $p a ́-$, used when second acts on first, suggests a ranking of first over second. This is not supported by the pronominal enclitics. Only the second person enclitic is used when second person acts on first as in examples (7) and (8). And, the complex pronominal

\footnotetext{
${ }^{5}$ There is one primary stress per spoken word, indicated here with an acute accent in the transcription for words of more than one syllable. The morpheme break line indicates roots and affixes with inherent stress. See Hargus and Beavert 2002, 2006 for more information about Yakima Sahaptin stress.
} 
=mash, used when first acts on second as in example (6), is also used to indicate second person possession. So, no enclitic used in local scenarios uniquely identifies first person. This suggests a ranking of second over first.

\subsection{Non-local}

In $3 / 3$ scenarios speakers choose from two constructions, labeled here direct and inverse. The Sahaptin system is similar to the Algonquian prototype, in that third persons are divided into proximate (PRX) and obviative (OBV) categories. When the more topical or salient 3PRX is acted on by the less topical $3 \mathrm{OBV}$, the inverse is triggered. ${ }^{6}$ A number of factors lead to a Yakima speaker's use of inverse versus direct voice. These fall under broad areas of topicality, topic switching, empathy and animacy. Speaker and genre also play a role. (See Rude 1994, Blackburn Morrow 2006, Jansen 2010 for more on the factors conditioning the use of inverse voice in Sahaptin.)

In (9), a direct clause, the verb is prefixed with 3SG.S/A prefix $i$-. The A is not case marked. The human $\mathrm{O}$ is.

$$
\begin{aligned}
& \text { iwáwyaxana myánashmaman wawyałá } \\
& \text { i-wáwya-x̌a-na myánash-maman wawyałá-Ø } \\
& \text { 3SG.S/A- whip-HAB-PST child-OBJ.PL whipman- } \varnothing \\
& \text { 'the whipman used to whip the children' }
\end{aligned}
$$

In example (10), the inverse is indicated by the verbal prefix pá- and ergative case-marker -in marking the A (-yin here as it follows a vowel). If there were a nominal object in (10), it would necessarily take an object marker.

$$
\begin{aligned}
& \text { Chaw pák'inuta wisalilłáyin } \\
& \text { Chaw pá-ḱinu-ta wisalilłá-yin } \\
& \text { NEG INV-see-FUT hunter-3>3.ERG } \\
& \text { 'the hunter will not see them' }
\end{aligned}
$$

Animacy of $\mathrm{A}$ and $\mathrm{O}$ interacts with the use of inverse, in that topicality and animacy overlap (see Givón 1984). In Sahaptin, however, inanimate arguments can be either the A or O of an inverse clause, as seen in the following.

$$
\begin{aligned}
& \text { ku kwnak wítxuptin páwinpa } \\
& k u \quad k \text { wnak wítxupt-in pá-Wínp-a } \\
& \text { and there blizzard-3>3.ERG INV-take-PST } \\
& \text { 'and there the bitter blizzard caught them' }
\end{aligned}
$$

\footnotetext{
${ }^{6}$ The morphosyntax of Algonquian languages is not necessarily as neatly organized as this suggests, see Rhodes 1994; Zúñiga 2008.
} 
(12)

\begin{tabular}{|c|c|c|c|}
\hline $\begin{array}{l}\text { anakú } \\
\text { when }\end{array}$ & $\begin{array}{l}\text { pá-tamanwi-ya } \\
\text { INV-create-PST }\end{array}$ & $\begin{array}{l}\text { íchinak } \\
\text { this.OBJ }\end{array}$ & $\begin{array}{l}\text { tiichám-nan } \\
\text { earth-OBJ }\end{array}$ \\
\hline $\begin{array}{l}k u \\
\text { and }\end{array}$ & $\begin{array}{l}\text { pá-tamánwi-ya } \\
\text { INV-create-PST }\end{array}$ & $\begin{array}{l}\text { k'usík'usi-nan } \\
\text { dog-OBJ }\end{array}$ & \\
\hline
\end{tabular}

'When he created this earth, he also created dogs.'

\subsection{Summary of monotransitive clauses}

To sum up, monotransitive clauses reflect a ranking of participants, with SAP's outranking third person and 3PRX outranking 3OBV. There is grammatically obligatory hierarchical alignment in local and mixed scenarios. Non-local 'optional' voice constructions show a direct/ inverse alternation.

Several things in particular stand out about the grammatical coding of monotransitive constructions. The morphology used for the various scenarios overlaps, but a unique combination codes each scenario. There are two ergative case markers, one (-nim) used when third person acts on an SAP, and a second (-in) used when $3 \mathrm{OBV}$ acts on $3 \mathrm{PRX} .^{7}$ The inverse marking prefix pá- is used in both local and non-local constructions. It is, in fact, the only verb prefix that indexes an SAP argument. However, it is not used in the core case of inverse directionality when third person acts on an SAP. An animacy hierarchy is at work in some places but not others. Inanimate As are not blocked from taking either of the two ergative markers. However, animacy is a key factor in differential object marking. Finally, Sahaptin displays tripartite alignment in nominal case marking, with $\mathrm{S}, \mathrm{A}$, and $\mathrm{O}$ uniquely identified in certain combinations. These three cases are seen in examples (13) and (14) below, with (13) showing an unmarked $S$ and (14) showing a marked $\mathrm{A}$ and $\mathrm{O}$.

ilalíwashana Waxpúuya

i-lalíwa-sha-na Waxpúuya-Ø

3sG.S/A-be.lonely-IMPV-PST Rattlesnake-Ø

'Waxpúuya (Rattlesnake) was lonely'

pátmiyúuna Spilyáyin Twit'áayanan

pá-tmiyúu-na Spilyáy-in Twit'áaya-nan

INV-plot.against-PST Coyote-3>3.ERG Grizzly.Bear-OBJ

'Spilyáy (Coyote) schemed against Twit'áaya (Grizzly)'

Table 1 reviews the morphological coding of monotransitive clauses across persons.

\footnotetext{
${ }^{7}$ Scott DeLancey (personal communication) proposes that this pattern of ergative case marking is not attested elsewhere and may be unique to Sahaptin.
} 


\begin{tabular}{|c|c|c|c|c|c|c|}
\hline Scenario & $\mathbf{A}$ & $\mathbf{O}$ & $\begin{array}{l}\text { pronominal } \\
\text { enclitic }\end{array}$ & verb prefix & $\begin{array}{l}\text { A case } \\
\text { marking }\end{array}$ & $\begin{array}{l}O \text { case } \\
\text { marking }\end{array}$ \\
\hline \multirow{2}{*}{ Local } & $1 \mathrm{SG}$ & $2 \mathrm{SG}$ & $=\operatorname{mash}^{\prime} 1>2$ ' & - & ABS PN & OBJ PN \\
\hline & $2 \mathrm{SG}$ & $1 \mathrm{SG}$ & $=$ nam '2 $2 \mathrm{sG}$ ' & pá- 'INV' & ABS PN & OBJ PN \\
\hline \multirow{2}{*}{ Mixed } & SAP & $3 \mathrm{SG}$ & $\begin{array}{l}=\text { nash ' } 1 \mathrm{SG} \text { ' } \\
=\text { nam ' } 2 \mathrm{sG} \text { ' }\end{array}$ & á- ‘30’' & ABS PN & $(-n a n$ 'овJ') \\
\hline & $3 \mathrm{SG}$ & SAP & $\begin{array}{l}=\text { nash ' } 1 \mathrm{SG} \text { ' } \\
=\text { nam ' } 2 \mathrm{sG}\end{array}$ & $i-$ '3SG.S/A' & -nim & OBJ PN \\
\hline \multirow{2}{*}{ Non-local } & 3SG.PRX & 3SG.OBV & - & $i-$ '3SG.S/A' & $-\varnothing$ & $(-n a n$ 'OBJ') \\
\hline & 3SG.OBV & 3SG.PRX & - & pá- 'INV' & $-i n$ & -nan ‘ОВJ' \\
\hline
\end{tabular}

Table 1: Summary of formal properties of Transitive clauses with singular A

${ }^{\dagger}$ Recall that $\mathrm{A}$ and $\mathrm{O}$ may not be overt, so case marking may not appear in the clause. These columns indicate what form A and $\mathrm{O}$ will take if overt. Parentheses indicate optionality; -nan 'OBJ' is not obligatory in some scenarios.

\section{Ditransitive Constructions}

In turning now to look at ditransitive constructions, we continue to see influences of person, animacy and topicality hierarchies. Ditransitives make use of the same morphosyntax as is described for monotransitives above with the addition of a dative case marker. Whether the Recipient/goal (R) or Theme (T) is case-marked the same way as is monotransitive $\mathrm{O}$ varies. (For the purposes of this paper, the roles of Recipient and Goal are conflated, based on the parallel treatment of these in ditransitives.) Ditransitive patterns are as follows:

(i) Indirective type: In some ditransitive constructions, the $\mathrm{T}$ is marked as is monotransitive O. So, we see a direct object/indirect object distinction following Dryer 1986, or indirective alignment as described by Haspelmath 2005.

(ii) Secundative type: In other constructions, the $\mathrm{R}$ is marked as is monotransitive $\mathrm{O}$, showing a primary/secondary object pattern (Dryer 1986), or secundative alignment (Haspelmath 2005).

(iii) Neutral type: Finally, in rare instances double object marking is possible, in which both $\mathrm{T}$ and $\mathrm{R}$ are marked in the same way as the $\mathrm{O}$ of a monotransitive, showing neutral alignment.

Like the hierarchical alignment and inverse voice systems described above for monotransitives, the Sahaptin system is split. In some R/T scenarios a Sahaptin speaker can choose whether to code $\mathrm{R}$ and/or $\mathrm{T}$ as the object (that is to say, in the same way as monotransitive $\mathrm{O}$ ), but sometimes there is an obligatory coding of either the $\mathrm{R}$ or $\mathrm{T}$ as the object.

The following sections consider only three-participant clauses that have the flagging and indexing patterns of the prototypical ditransitives described in the section 3.1 below. This disregards some three-participant constructions in which one participant is marked as an instrument, source or location. ${ }^{8}$ The three-participant constructions included here consist of three

\footnotetext{
${ }^{8}$ Most of the three-participant constructions this excludes do not occur with a human $\mathrm{T}$ and $\mathrm{R}$ and they show no alternations in marking; the location, source or instrument is case-marked as such. Verbs of deprivation (tyaníp- take
} 
underived and two derived classes of ditransitive verbs. The classes are based on semantic features as well as the grammatical coding of $\mathrm{T}$ and $\mathrm{R}$. The classes are as follows: Class one: 'give' type verbs (discussed in Section 3.1); Class two: verbs of placing into (Section 3.2); Class three: verbs of speaking (Section 3.3); Derived class one: applicatives (Section 3.4); Derived class two: causatives (Section 3.5). Of particular interest to the discussion are 'give' verbs (Section 3.1) and those derived with the causative (Section 3.5), as these are the classes that show alternation and choices in coding.

\subsection{Grammatical coding of prototypical ditransitives}

This section looks at the coding of $\mathrm{T}$ and $\mathrm{R}$ in prototypical ditransitive constructions that follow the pattern of the verb ní- 'give'. Examples below also use isíkw'a- 'show'. Other verbs that have the same pattern are verbs of trading, selling, renting, lending, such as wámshi- 'loan, borrow, rent' and itáyma- 'sell'. In these ditransitive clauses, four nominal case markers are used. Two are the ergative case markers $-n \dot{m}$ (used with 3>SAP) and -in (used with 3OBV>3PRX). The object marker -nan marks $\mathrm{T}$ or $\mathrm{R}$. Dative case marker -yaw can also mark $\mathrm{R}$. The case marker -yaw typically indicates motion to or into the noun it is suffixed to. It implies that a specific destination was reached and/or entered. It also has a range of more abstract meanings. In some participant combinations, as will be seen below, arguments are not case marked.

Most typically, one of the non-A arguments in a ditransitive is human and the other is not. (The rare cases in which both $\mathrm{T}$ and $\mathrm{R}$ are human will be addressed below.) When a human is $\mathrm{R}$ and $\mathrm{T}$ is nonhuman (as is most common), the human is object-marked. Compare the following monotransitive, example (15), with the ditransitive in (16). In the monotransitive clause in (15), the object $t$ 'aaxw 'all' has the plural object marker -maman. The same form is seen in ditransitive example (16), coding the R. With a non-human $\mathrm{T}$ and human $\mathrm{R}$, this coding is obligatory. Rude (1997, 2009) calls this obligatory dative shift, and it is the most common pattern for this class of ditransitives.

iwáwtłika tł'aaxwmaman

i-wáwtlik-a t' t'aaxw-maman

3SG.S/A-beat.to.death-PST all-PL.OBJ

'he beat everyone to death'

tł'aaxwmaman iníya tkwátat

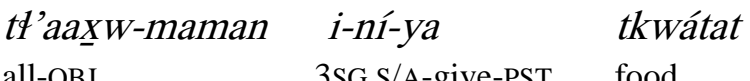

'heBj

'he gave everyone food'

by force, páxwi- 'steal') can occur with human $\mathrm{T}$ and $\mathrm{R}$. They follow the same obligatory and optional patterns of alternation as 'give'-type verbs in that source or theme may be marked as the object, but the alternation is with the ablative rather than the dative. Yakima consultants felt a slight meaning difference between a semantic source marked $\mathrm{OBJ}$ and the same source marked ABL, with the examples in which the source was marked by ablative rather suggesting a physical location (for example, taken by force 'from the woman's place' vs. 'from the woman'). See Rude 1997 for CR and NE Sahaptin examples. 
Ditransitives with a human $\mathrm{T}$ are very uncommon. In addition, in Sahaptin participants are often covert. For these reasons, the discussion here of constructions in which $\mathrm{T}$ and $\mathrm{R}$ are both human and overtly expressed relies on a limited number of elicited examples.

A second pattern of obligatory coding in ditransitive clauses occurs when the theme is a speech act participant. An SAP theme is always the grammatical object. It is necessarily coded with the second position pronominal enclitic, indicating that it is a core argument of the verb, as seen in the monotransitive examples in the preceding section. If independent pronouns are used, as in the examples below, the object pronoun is used to reference the $\mathrm{T}$. The $\mathrm{R}$, if overt, is marked by a pronoun in the dative case or by dative case marking on a noun. If the referent is human, the genitive marker -mí precedes the benefactive, dative, allative, ablative, instrumental, and locative case endings. This serves in ditransitives to further mark the $\mathrm{R}$ as human.

The following examples present clauses with SAP themes. Independent pronouns and clitics indicate $\mathrm{T}$ and $\mathrm{R}$.

inák nash iníya imyúuk

\begin{tabular}{|c|c|c|c|}
\hline inák & $=$ nash & $i-n i ́-y a$ & imyúuk \\
\hline 1SG.PN.OBJ & $=1 \mathrm{SG}$ & 3SG.S/A-give-PST & 2SG.PN.DAT \\
\hline \multicolumn{4}{|c|}{ 's/he gave me to you' } \\
\hline \multicolumn{4}{|c|}{ imák nam iníya ayatmíyaw } \\
\hline imák & $=$ nam & i-ní-ya & áyat-mí-yaw \\
\hline 2SG.PN.OBJ & $=2 \mathrm{SG}$ & 3SG.S/A-give-PST & woman-GEN-DAT \\
\hline
\end{tabular}

The grammatical coding of $\mathrm{T}$ and $\mathrm{R}$ in the preceding examples is obligatory. A $\mathrm{T}$ whose referent is an SAP is always encoded as the object.

However, if $\mathrm{T}$ is third person and both arguments are human, there are two possibilities. Either $\mathrm{T}$ or $\mathrm{R}$ can be marked as the grammatical object, so, either an indirective or secundative pattern is grammatical. If $\mathrm{R}$ is the grammatical object, as in the following, $\mathrm{T}$ is not case marked. Below, iwínsh 'man' is unmarked.

$$
\begin{array}{lll}
\text { awisíkw’anaash íwínsh áyatnan } & \\
\text { áw-isíkw'a-na =nash } & \text { iwínsh } & \text { áyat-nan } \\
\text { 3o-show-PST=1sG } & \text { man } & \text { woman-OBJ }
\end{array}
$$

'I showed the woman the man'

If the $\mathrm{T}$ is marked as the object, as in (20), the $\mathrm{R}$ is marked with dative $-y a w$. 
i'isíkw'ana i iwínshnan ayatmíyaw

i-isíkw'a-na iwínsh-nan ayat-mí-yaw

3SG.S/A-show-PST man-OBJ woman-GEN-DAT

's/he showed the man to the woman'

If the $\mathrm{R}$ is an SAP and the $\mathrm{T}$ is third person human, the coding of $\mathrm{T}$ and $\mathrm{R}$ is the same as seen in the previous scenario. If the $\mathrm{T}$ is the grammatical object, indicated below with object case marking on iwinsh 'man', then the overt SAP R is in the dative case.

\begin{tabular}{|c|c|c|}
\hline iwínsh-nan & i-isíkw’a-na & inmíyaw \\
\hline $\begin{array}{l}\text { man-OBJ } \\
\text { 's/he showe }\end{array}$ & $\begin{array}{l}\text { 3SG.S/A-show-PST } \\
\text { the man to me' }\end{array}$ & 1SG.PN.DAT \\
\hline
\end{tabular}

If the SAP R is indexed with a pronominal enclitic, it is the grammatical object and the third person $\mathrm{T}$ is unmarked.

$$
\begin{aligned}
& \text { twínsh nash i'isíkw'ana } \\
& \text { iwínsh = nash i-isíkw'a-na } \\
& \text { man =1SG 3sG.S/A-show-PST } \\
& \text { 'They showed me the man' }
\end{aligned}
$$

The above examples and discussion have looked at 'give'-class ditransitive constructions. Within this class, there are a variety of case-marking patterns, some obligatory and some optional. We see that person and animacy affect the coding of $\mathrm{T}$ and $\mathrm{R}$ arguments in these ditransitives. Topicality also has an effect. Rude $(1997,2009)$ reviews behavior and control criteria for objecthood in Sahaptin ditransitives and concludes that the grammatical objects of ditransitives have the properties of objects of monotransitive clauses. In the cases where there are alternate possibilities for coding in ditransitives, Rude's analysis is that the grammatical object is being highlighted, and the unmarked or dative-marked noun is less important. We will now look at additional classes of verbs.

\subsection{Class two: verbs of putting}

A second set of three-participant verbs lexically requires the dative to be used to mark $\mathrm{R}$. These have broad meanings surrounding putting, placing, throwing, and attaching. The $T$ is differentially marked as the object. The result is a three-participant indirective construction with A unmarked or marked ergative; $\mathrm{T}$ unmarked or marked as the object, and $\mathrm{R}$ marked dative. The indexing and flagging on (23) below is the same as the 'give' example in (20) above (although the non-human goal in (23) does not take the genitive as well as the dative case marker).

\footnotetext{
${ }^{9}$ The $3^{\text {rd }}$ person singular prefix $i$ - often deletes before a vowel-initial verb, but it was retained in these elicited examples.
} 
Uyt ipáxnan áyat patamaníixa chíishyaw

$\begin{array}{llll}\text { uyt ipáx-nan } & \text { áyat } & \text { i-tamaníi-xa } & \text { chíish-yaw } \\ \text { first hide-OBJ } & \text { woman } & \text { 3sG.S/A-throw.in.water-HAB } & \text { water-DAT }\end{array}$

'First the woman puts the hide in water'

Object marking of $\mathrm{T}$ is not required. Whether or not $\mathrm{T}$ is marked, $\mathrm{R}$ retains dative marking. The example below, from the same text, has the same verb as in (23) with a dative $\mathrm{R}$ and an unmarked $\mathrm{T}$.

$\begin{array}{lll}\text { Yaamashmí ipáx áyat itamaníixa tkwsáyyaw } & \\ \text { yaamashmí ipáx áyat itamaníixa } & t k w s a ́ y-y a w \\ \text { mule.deer-GEN } \text { hide woman 3SG.S/A-throw.in.water-HAB } & \text { bucket-DAT } \\ \text { 'Women throw the deer hide into a container' } & \end{array}$

There are no text examples with a human $\mathrm{T}$ and human $\mathrm{R}$ for these verbs; elicited examples also mark $\mathrm{R}$ with the dative if the referent is human.

\section{$(25)$}
itamáwaykta myánashnan ayatmíyaw
i-tamáwayk-ta
myánash-nan
3SG.S/A-throw.across-FUT child-OBJ
ayat-mí-yaw.
's/he will throw the child across to the woman'

So, unlike the 'give' class, this class does not show an alternation between indirective and secundative alignment.

\subsection{Class three: verbs of speaking}

Verbs of speaking, telling and asking occur only with an inanimate $\mathrm{T}$ and an animate $\mathrm{R}$. The $\mathrm{T}$ is the thing said while the R, encoded as the object, is the person spoken to. The alignment is secundative. In (26), áyat 'woman' has the object marker -nan. íkw'ak 'that' is the absolutive form of the distal demonstrative.

$$
\begin{aligned}
& \text { ku íkw'ak ína ḱáxnu áyatnan } \\
& \text { ku íkw'ak inn-a ḱáxnu áyat-nan } \\
& \text { and that tell-PST prairie.chicken woman-OBJ } \\
& \text { 'Prairie chicken said that to his wife' }
\end{aligned}
$$

Text examples show that a subclass of verbs exists in which something asked for, thanked for or prayed for is optionally marked with dative -yaw. The dative marker is seen in (27), however it is not present in (28), a clause using the same verb and from the same speaker. 
áwatt'awyaash nch'ínch'imaman piimyúuk sápsikw'atyaw áw-atł'awi-ya =ash nch'ínch'imaman piimyúuk sápsikw'at-yaw 3O-ask.for-PST=1SG elder-PL.OBJ their.DAT teaching-DAT 'I asked the elders for their teachings'

(28) áwatł’awita nam sápsikw’at nch'ínchimaman ttáwaxtmaman

$\begin{array}{llll}a ́ w \text {-atł’áwi-ta }=\text { nam } & \text { sápsikwaat- } \varnothing & \text { nch'ínch'i-maman } & \text { ttáwaxt-maman } \\ \text { 3O-ask.for-FUT=2SG } & \text { teaching- } \varnothing & \text { elder-PL.OBJ } & \text { family-PL.OBJ }\end{array}$

'you will ask the family elders for their teaching'

\subsection{Derived: Applicatives}

Applicatives add a syntactic object to the clause. These added arguments are benefactor/ possessor (-ani), goal (-uu) or associative (-twii). The added argument, if overtly expressed by a noun, is necessarily marked with the object marker -nan. This added argument is almost always human; I have only a few examples of a (non-legendary) animal with a prominent role in a text being added as an object via an applicative construction. Inanimates are never treated this way. The following example shows the use of applicatives to derive a monotransitive from intransitive walptáyk- 'sing'.

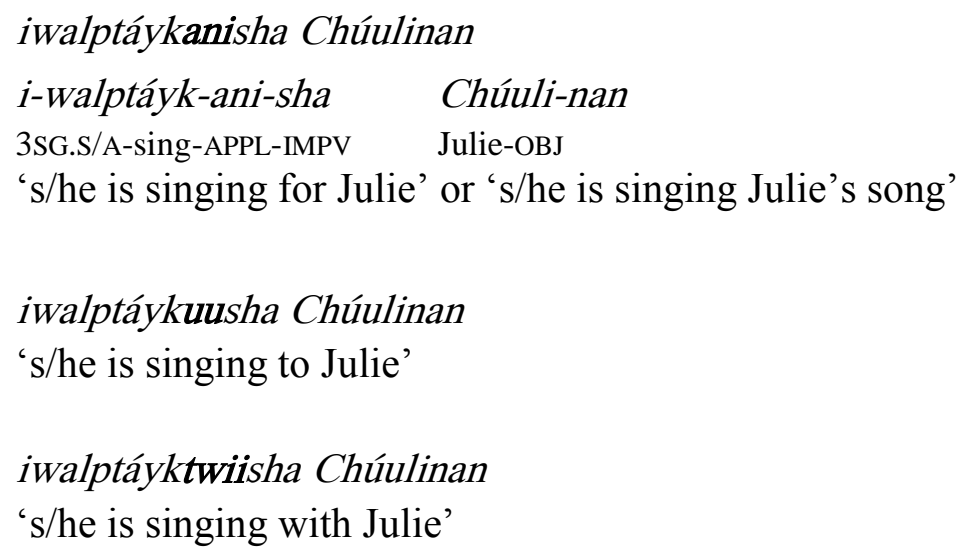

Applicatives also add arguments to monotransitive verbs, deriving ditransitives. The end result is that a human/animate argument becomes the grammatical object and any previous object is 'demoted' and left unmarked. Double object marking does not occur, nor is any other case marker used on the demoted object.

In (30) below, the applicative ani- adds an object to a transitive verb. The benefactor is marked as the object. In (31), a possessor is added, using the same applicative. The possessor is case marked as the object; the unmarked is the inanimate possessed thing. 
ku paníchanixana awkú pawawyałánan

kú pa-ních-ani-x̃a-na awkú pawawyałá-nan

and 3PL.S/A-put-APPL-HAB-PST then whipman-OBJ

'and they would put some away then for the whipman'

paḱn'ínunaniya wátiksh Spilyáynan

pa-ǩn'ínu-nani-ya wátiksh Spilyáy-nan.

3PL.S/A -see-APPL -PST tracks Coyote-OBJ

'They saw Coyote's tracks.'

Example (32) shows the applicative - $u u$ (here -núu) adding a goal to a monotransitive verb, resulting in a ditransitive. This applicative was seen in (29) adding a more abstract addressee, but its core meaning refers to the physical location of the added human argument. The human goal is object marked; the $\mathrm{O}$ of the original clause is unmarked.
awat'anúunaash shp'aw áyatnan
á-wát'a-núu-na =ash shp'aw áyat-nan
3o-hit-APPL-PST=1SG ball woman-OBJ
'I hit the ball to the woman'

The associative applicative is seen in (33) with the monotransitive verb twána- 'follow'. The grammatical object is the added argument.

itwanatwíishana áyat iwínshnan

i-twána-twí-sha-na áyat iwínsh-nan
3SG-follow-APPL-IMPV-PST woman man-OBJ
'S/he with the man was following the woman'

There are no alternations in marking in the class of ditransitives derived by applicatives.

\subsection{Derived: Causatives}

The causative prefix shapá-alters the inherent transitivity of a verb by adding an A (marked as is any other A) to the clause. shapá- derives monotransitives from intransitives, and ditransitives from monotransitives. In monotransitive causatives, the causee becomes the grammatical object. Example (34) shows the intransitive verb tux- 'return, return home'. The first person singular subject is indicated with the enclitic =nash. When the causative prefix is added, as in (35), the third person $\mathrm{A}$ is indicated by the verb prefix $i$-. The first person object is indicated with $=$ nash. 
aw nash túx sha

$$
\begin{aligned}
& \text { aw =nash túx-sha } \\
& \text { now =1SG go.back-IMPV } \\
& \text { 'I'm going home now' }
\end{aligned}
$$

$$
\begin{aligned}
& \text { ishapátuxnimshnash } \\
& \text { i-shapá-túx-nim-sh }=\text { nash } \\
& \text { 3sG.S/A-CAUS-go.back-CSL-PPF=1SG } \\
& \text { 'he has made me come back' }
\end{aligned}
$$

The causative codes successful manipulation and can indicate a range of action from stronger 'make' or 'force' to less forceful 'have' or 'let'.

The following examples show causatives added to monotransitive verbs. In the derived ditransitive, most often the causee (the A of the original clause) becomes the marked object, with the third argument (the $\mathrm{O}$ of the original clause) unmarked. As has been seen throughout, animacy is a key factor. If the $\mathrm{O}$ of the original clause is non-human and the causee is human, the causee is obligatorily marked and the original O left unmarked, as in (36).

awkú nash áshapa'imałaka áyatnan iníit

$\begin{array}{llll}\text { awkú =nash } & \text { á-shapá-ímałak-a } & \text { áyat-nan } & \text { iníit } \\ \text { then }=1 \mathrm{SG} & \text { 3O-CAUS-clean-PST } & \text { woman-OBJ } & \text { house } \\ \text { 'I had the woman clean the house' } & & \end{array}$

In example (37) sapsíkwa- 'teach' is lexicalized, but its form is analyzable as sáp-isíkw’a 'CAUS.PL-show'.

$$
\begin{aligned}
& \text { ásapsikwanxaaash íchi myánashmaman } \\
& \text { á-sápsikw'a-nxa =ash íchi myánash-maman } \\
& \text { 3o-teach-HAB=1SG this child-3PL.OBJ }
\end{aligned}
$$

'I teach this to the children'

In the preceding examples we see a lack of alternation in the case marking: one argument is human, the second is not, and the human participant is case marked as the object. The following examples show the patterns that occur when both the A of the original clause (the causee) and the $\mathrm{O}$ of the original clause are human. Again, since phrases with three human arguments do not typically show up in discourse, many of these grammatically acceptable examples are somewhat odd to speakers.

When the $\mathrm{A}$ of the original clause is human and the $\mathrm{O}$ of the original clause is human and third person, the same possibility exists as in the 'give' class. Either the causee or the $\mathrm{O}$ of the original clause can be object-marked with -nan. Typically it will be the causee. The $\mathrm{O}$ of the original clause is unmarked. This patterns with the secundative 'give' class examples in which the $\mathrm{R}$ is object-marked and the $\mathrm{T}$ unmarked, seen in (19) and (22) above. 
awkú nash áshapanaktkwanina myánash áyatnan

$\begin{array}{llll}\text { awkú =nash } & \text { á-Shapá-náktkwanin-a } & \text { myánash } & \text { áyat-nan } \\ \text { then=1SG } & \text { 3o-CAUS-care.for-PST } & \text { child } & \text { woman-OBJ } \\ \text { 'I had the woman take care of the child' } & & \end{array}$

If instead the grammatical object of the derived ditransitive is the $\mathrm{O}$ of the original clause, the causee is marked dative. Example (39) mirrors (20) and (21) in morphological coding, with the causee marked as R.

$$
\begin{aligned}
& \text { awkú nash áshapanaktkwanina myánashnan ayatmíyaw } \\
& \begin{array}{llll}
\text { awkú= nash á-shapá-náktkwanin-a myánash-nan } & \text { ayat-mí-yaw } \\
\text { then=1SG } & \text { 3O-CAUS-care.for-PST child-OBJ } & \text { woman-GEN-DAT } \\
\text { 'I had the child cared for by the woman' } &
\end{array}
\end{aligned}
$$

Unlike the 'give' class, we find examples of causative ditransitives with double object marking in which roles are differentiated only by word order. The causee precedes the $\mathrm{O}$ of the original clause.

$$
\begin{aligned}
& \text { awkú nash áshapanaktkwanina áyatnan myánashnan } \\
& \begin{array}{llll}
\text { awkú =nash á-shapá-náktkwanin-a áyat-nan } & \text { myánash-nan } \\
\text { then =1SG } & \text { 3o-CAUS-care.for-PST } & \text { woman-OBJ } & \text { child-OBJ } \\
\text { 'I had the woman take care of the child' } & &
\end{array}
\end{aligned}
$$

I could elicit these examples, but they were odd to consultants and are not found in texts. Note that this is the only instance in Sahaptin in which word order determines grammatical relations (see Rude 2009).

Recall that in 'give' class verbs, an SAP T is necessarily the grammatical object, as seen in (17) and (18) above. In causative ditransitives, SAP's again have special status with regards to object marking, although this is not the same pattern as with 'give' verbs. An SAP that is the O of the original clause can be marked one of two ways in a causative ditransitive. If it is the grammatical object, coded by an enclitic, the causee is marked with the dative.

$$
\begin{aligned}
& \text { ishapánaktkwaninaash iwínshmíyaw } \\
& \text { i-shapá-náktkwanin-a =ash íwínsh-mí-yaw } \\
& \text { 3SG.S/A-CAUS-care.for-PST=1SG man-GEN-DAT } \\
& \text { 's/he had me cared for by the man' }
\end{aligned}
$$

The first person object pronoun inák could be used in the above clause, yielding inák nash ishapánaktkwanina iwinshmíyaw.

A second construction used when an SAP is the $\mathrm{O}$ of the original clause marks the causee as the object, seen below in the object case marker on iwinsh 'man'. The SAP is then not indicated by a second position enclitic. However, the SAP object pronoun is used, forming a construction with double object marking. 
ishapánaktkwanina iwínshnan inák

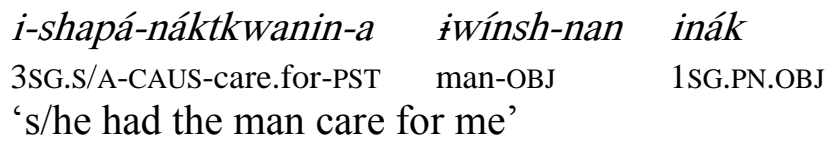

Since the SAP enclitic is not present, the SAP in the above example is downgraded - not a 'true' grammatical object. While grammatical, the double object constructions are not preferred. Speakers prefer (41) to (42), and can readily present more natural periphrastic alternatives (e.g. 'She asked the man. He cared for me'). As for behavior and control criteria in causative constructions with two objects marked, the causee (the A of the original clause) retains object properties (Rude 1997, 2009).

\section{Summary and Conclusions}

We have seen in the sections above that Yakima Sahaptin has multiple monotransitive and ditransitive constructions. Looking at case-marking of monotransitives, we find a tripartite system. In terms of ditransitive alignment, again considering case-marking, the language exhibits all the alignment patterns described in Haspelmath (2005), and in this way could be described as showing tripartite ditransitive alignment as well. Two of the classes described here, the 'give' verbs and ditransitives derived with the causative prefix shapá-, show class-internal variation.

Haspelmath gives evidence that for the most part within languages, the ditransitive alignment type used is independent of the monotransitive alignment type (2007, 6). Sahaptin shows a parallel between monotransitive alignment and ditransitive alignment in that the language overcodes participants; multiple cues point to each referent. In speaking of tripartite systems such as Sahaptin's, Mithun (1999) suggests that their rarity has to do with the fact that is it not maximally efficient, as only two arguments need to be distinguished in any given clause (see also Comrie 1978). This lack of economy in monotransitives is seen in the argument coding of ditransitives in Sahaptin, in which the following are all case-marking possibilities: $\mathrm{T}=\varnothing, \mathrm{R}=\mathrm{OBJ}$; $\mathrm{T}=\mathrm{OBJ}, \mathrm{R}=\mathrm{DAT} ; \mathrm{T}=\varnothing, \mathrm{R}=\mathrm{DAT} ; \mathrm{T}=\mathrm{OBJ}, \mathrm{R}=\mathrm{OBJ}$. Table 2 presents the possibilities for the two alternating classes of three participant verbs.

\begin{tabular}{|c|c|c|}
\hline & Coding of $T, R$ & Alignment \\
\hline $\begin{array}{l}\text { Class one: } \\
\text { 'give' type verbs }\end{array}$ & $\begin{array}{l}\mathrm{T}=\emptyset, \mathrm{R}=\mathrm{OBJ} \\
\mathrm{T}=\mathrm{OBJ}, \mathrm{R}=\mathrm{DAT}\end{array}$ & $\begin{array}{l}\text { secundative } \\
\text { indirective }\end{array}$ \\
\hline $\begin{array}{l}\text { Derived class two: } \\
\text { causatives }\end{array}$ & $\begin{aligned} \mathrm{T} & =\emptyset, \mathrm{R}=\mathrm{OBJ} \\
\mathrm{T} & =\mathrm{OBJ}, \mathrm{R}=\mathrm{DAT} \\
\mathrm{T} & =\mathrm{OBJ}, \mathrm{R}=\mathrm{OBJ}\end{aligned}$ & $\begin{array}{l}\text { secundative } \\
\text { indirective } \\
\text { neutral }\end{array}$ \\
\hline
\end{tabular}

Haspelmath (2007), looking only at 'give'-verbs across languages, discusses the tendency for economical flagging to predominate, and points to Sahaptin as a counter-example (11). This paper broadens the verb classes discussed, and shows additional ways in which Sahaptin violates the principle of economy.

Hierarchies of person, animacy and topicality affect both monotransitive and ditransitive clauses in Sahaptin. In addition, the language contains obligatory as well as optional monotransitive and ditransitive constructions. In monotransitives, SAP/SAP and 3/SAP 
constructions are fixed-choice, based on a person-hierarchy. In the ditransitive 'give' class, a person-based hierarchy is apparent in that an SAP T must be the grammatical object. An animacy hierarchy plays a role in monotransitive differential object marking, in which a human object is case-marked, while an animate or non-human argument is optionally marked. In the most typical ditransitives, the $\mathrm{T}$ is non-human and unmarked, and the human $\mathrm{R}$ is necessarily case marked as the object. When $\mathrm{T}$ is human and $\mathrm{R}$ is not, it is the $\mathrm{T}$ that will have the object case marker. Thus the language also exhibits differential R marking (see Kittilä2008).

Monotransitive $3 / 3$ constructions give speakers a choice of two coding strategies. The use of the inverse as opposed to the direct voice is broadly based on a topicality hierarchy. Similarly, 'give'-class ditransitives with a third person human theme and a human recipient allow speakers to code either the $\mathrm{R}$ or the $\mathrm{T}$ as the grammatical object. Causative ditransitives also allow for this choice, with no person restrictions. More work is called for to determine what conditions this coding choice. Rude (1997) suggests it is based on topicality, with the object-marked T or R being the highlighted participant. This corresponds to Haspelmath's claim that $\mathrm{R}$ is more likely to be specially-marked the lower it is on animacy, definiteness, and person scales $(2007,83)$. Determining the specific factors that condition the inverse/direct alternation within monotransitives may shed light on ditransitive alternations as well.

\section{References}

Beavert-Martin, Virginia R. 1999. Native songs taught by Ellen W. Saluskin (Hoptonix Sawyalilx_. Spirit of the First People: Native American Music Traditions of Washington State, ed. by Esme Ryan and Willie Smythe, 62-71. Seattle: University of Washington Press.

Blackburn Morrow, Jesse. 2006. Topicality and the inverse voice in Umatilla Sahaptin: an experimental study. M.A. thesis, University of Oregon.

DeLancey, Scott and Victor Golla. 1997. The Penutian hypothesis: Retrospect and prospect. International Journal of American Linguistics. 63:171-202.

Dixon, Robert M. W. 1994. Ergativity. Cambridge: Cambridge University Press.

Dryer, Matthew S. 1986. Primary objects, secondary objects, and antidative. Language

62:808-845.

Comrie, Bernard. 1978. Ergativity. Syntactic typology, ed. by Winfred P. Lehman, 329-94. Austin: University of Texas Press.

Givón, Talmy. 1984. Syntax: A Functional-Typological Introduction, Volume 1. Amsterdam: John Benjamins.

Hargus, Sharon and Virginia Beavert. 2002. Predictable versus underlying vocalism in Yakima Sahaptin. International Journal of American Linguistics 68:316-40.

-----. 2006. High-ranking affix faithfulness in Yakima Sahaptin. Proceedings of the 25th West Coast Conference on Formal Linguistics, ed. by Don Baumer, David Montero and Michael Scanlon, 177-185. MA: Cascadilla Proceedings Project.

Haspelmath, Martin. 2005. Argument marking in ditransitive alignment types. Linguistic Discovery 3:1-21.

-----. 2007. Ditransitive alignment splits and inverse alignment. Functions of Language 14:79102.

Jansen, Joana. 2010. A Grammar of Yakima Ichishkíin /Sahaptin. PhD diss., University of Oregon. 
Kittilä, Seppo. 2008. Animacy effects on differential Goal marking. Linguistic Typology 12:245268.

Mithun, Marianne. 1999. The Languages of Native North America. Cambridge, UK: Cambridge University Press.

Nichols, Johanna. 1992. Linguistic Diversity in Space and Time. Chicago: University of Chicago Press.

Rhodes, Richard. 1994. Agency, inversion and thematic alignment in Ojibwe. Berkeley Linguistics Society 20:431-446.

Rigsby, Bruce. 1965. Linguistic relations in the southern plateau. $\mathrm{Ph} \mathrm{D}$ diss., University of Oregon.

Rude, Noel. 1994. Direct, inverse and passive in Northwest Sahaptin. In Voice and Inversion, ed. by Talmy Givón, 101-119. Amsterdam: John Benjamins.

-----. 1997. Dative shifting and double objects in Sahaptin. Grammatical Relations: A Functionalist Perspective, ed. by Talmy Givón, 323-349. Amsterdam: John Benjamins.

-----. 2009. Transitivity in Northwest Sahaptin. Journal of Northwest Linguistics 3:1-37.

Siewierska, Anna. 2004. Person. Cambridge: Cambridge University Press.

Zúñiga, Fernando. 2008. How many hierarchies, really? Evidence from several Algonquian languages. Scales, ed. by Marc Richards and Andrej Malchukov. Leipzig: Linguistische Arbeits Berichte.

Author's Contact Information:

Joana Jansen

Department of Linguistics, University of Oregon

1629 Moss Street

Eugene, Oregon 97403

jjansen@uoregon.edu 